\title{
DIRECT in vitro REGENERATION OF CASTOR BEAN PLANTS (Ricinus communis) USING EPICOTYLS
}

\author{
REGENERAÇÃO DIRETA in-vitro DE PLANTAS DE MAMONA (Ricinus communis) \\ USANDO EPICÓTILOS
}

\section{Alejandro GIL-CORREAL ${ }^{1}$; Catalina RESTREPO-OSORIO ${ }^{1}$; Javier Correa ÁLVAREZ ${ }^{1}$; Diego Fernando VILLANUEVA-MEJÍA ${ }^{1}$}

1. Research Group CIBIOP, Department of Biological Sciences, School of Sciences, EAFIT University. Medellín, Colombia. dvillanu@eafit.edu.co

\begin{abstract}
A regeneration protocol for castor bean plant (Ricinus communis) was successfully developed using epicotyl sections obtained from in vitro seedlings. The maximum number of induced shoots (4.3 shoots/explant) and highest shoots frequency $(75,56 \%)$ was obtained in WPM medium supplemented with TDZ $(1 \mathrm{mg} / \mathrm{L})$ and zeatin $(0.5 \mathrm{mg} / \mathrm{L})$, whereas the minimum number $(0.8$ shoots/explant $)$ and lowest shoots frequency $(37,78 \%)$ was obtained in medium containing TDZ $(1 \mathrm{mg} / \mathrm{L})$ and BAP $(0.5 \mathrm{mg} / \mathrm{L})$. The highest percentage of rooting $(93.3 \%)$ was obtained in a medium containing IBA $(1 \mathrm{mg} / \mathrm{L})$. These plants were transplanted in a mesh house and achieved a high adaptability to acclimatization, reaching $77 \%$ survival. On the other hand, the maximum elongation (height) during this stage was $7.9 \mathrm{~cm}$ in plants supplemented with WPM nutrients, whereas it was only $4.38 \mathrm{~cm}$ in control plants.
\end{abstract}

KEYWORDS: Organogenesis. Acclimatization. Rooting. Tropical Crop. Plant tissue culture. Oilseed crop.

\section{INTRODUCTION}

The castor bean (Ricinus communis) plant belongs to the Euphorbiaceae family, with the center of origin in Ethiopia (SINGH et al., 2015). The oil extracted from castor bean seeds is important due to the high proportion $(84 \%-90 \%)$ of ricinoleic acid (12-hydroxy-cis-9-octadecenoic acid), which is a monounsaturated hydroxy fatty acid, with a wide range of uses in the chemical, pharmaceutical, and cosmetic industries. It also has an important biotechnological value because it is used as a biofuel (SAILAJA; TARAKESWARI; SUJATHA, 2008; FERNÁNDEZ-MARTINEZ, J. M.; VELASCO, 2012; SINGH et al., 2015). The largest producers of castor bean seeds in the world are India, Mozambique, Paraguay, Brazil, and Thailand, representing approximately $90 \%$ of the world production ("FAOSTAT", 2014). Although the demand for castor oil has increased in world markets recently, the arable area for this plant in the tropics has been diminishing; therefore, it is necessary to develop biotechnological strategies that will enhance the production capacity and fatty acid content of this crop while using a smaller area for cultivation. Modern biotechnology offers such a solution through transformation methodologies that allow scientists to bring about or enhance desirable characteristics in a plant. However, to achieve effective production of biotechnological seedlings, it is necessary to develop castor bean regeneration protocols that facilitate the attainment of plants capable of producing more oil.

Establishing the optimal culture medium for the in vitro growth of any plant is challenging; castor bean is no exception. Generally, Murashige and Skoog (MS) basal medium in different concentrations has been successfully used for the growth of all the stages of castor bean plant (SUJATHA; REDDY, 1998; SUJATHA, M; MAKKAR, H; BECKER, K, 2005; AHN et al., 2007; AHN, CHEN, 2008). However, various difficulties have been reported in the culturing of different cultivation stages, such as low seed germination which does not exceed 50\% (MEDEROS MOLINA; SCHOBERT, 1995). Hence, finding an alternative basal medium will allow the optimization of growth conditions for this species. Additionally, due to the recalcitrant behavior of the species in vitro, only few cases of successful adventitious sprout regeneration have been reported for genetic improvement and as a method of propagation. In these recalcitrant species, starting from a poorly differentiated tissue, such as hypocotyls or epicotyls, is fundamental to induce organogenesis; however, few studies have reported successful regeneration from these explants in castor bean plants (SARVESH, A., RAM RAO, D. M.; REDDY, 1992). In this research, an efficient methodology was successfully developed for the in 
vitro establishment and regeneration of castor bean plants using direct organogenesis with epicotyls sections as initial explants.

\section{MATERIAL AND METHODS}

The development of the research project was carried out in the Plant Biotechnology Laboratory of EAFIT University, Medellin, Colombia.

\section{Plant material and culture conditions}

The experimental variety of castor bean seeds $R$. communis-02 (VERC-02), belonging to the germplasm seed bank of the Colombian Agricultural and Livestock Research Corporation (in Spanish, Corporación Colombiana de Investigación Agropecuaria or AGROSAVIA), was used as the initial material. This material was transferred to the field at La Teresita Farm located at 85 MASL in Caucasia, Antioquia, Colombia (756'29"; 75ㅇ'43") for the establishment of vegetative and productive cycles. For culture initiation, seeds from the first raceme of the plant's fruits were used. The seeds were scarified and dipped into an iodized solution for $1 \mathrm{~h}$. Then, they were incubated in Timorex solution (Syngenta, Basel Switzerland) (Terpinen-4ol and $\gamma$-terpinene; $2 \mathrm{ml} / \mathrm{L}$ ) for $2 \mathrm{~h}$ in a laminar flow cabinet and subsequently transferred to a solution containing vancomycin ${ }^{\circledR} \quad\left[\begin{array}{ll}50 & \mathrm{mg} / \mathrm{L}\end{array}\right]$ and cefotaxime ${ }^{\circledR}[100 \mathrm{mg} / \mathrm{L}]$ for $3 \mathrm{~h}$, followed by dipping in $70 \%$ ethanol for $1 \mathrm{~min}$ and $3 \%$ sodium hypochlorite solution for $25 \mathrm{~min}$. Next, the seeds were sown in the basal culture medium and kept in darkness for 30 days. A total of 225 explants were evaluated per repetition; the trial was performed in triplicate, and the percentage of contamination was determined after 15 days of sowing.

\section{Shoot induction and seedling regeneration}

Two-week-old epicotyls obtained from in vitro germinated seeds were sectioned and sown in a culture medium supplemented with copper sulfate $\left(\mathrm{CuSO}_{4}\right)$, different concentrations of growth regulators cytokinins, including thidiazuron (TDZ), zeatin, 6-( $\gamma, \gamma$-dimethylallylamino) purine (2iP), 6benzylaminopurine (BAP), kinetin and auxins, including indole-3-butyric acid (IBA) and 1naphthaleneacetic acid (NAA) at concentrations of $[0.5$ and $1.0 \mathrm{mg} / \mathrm{L}]$, respectively, and without hormone supplements for eight evaluated treatments (Table 1). The trial was developed with 15 explants per repetition and performed in triplicate. The following were the variables evaluated after 45 days in the culture medium: average number of shoots per explant, shoots frequency and percentage of shoots developed. The WPM basal medium was used for the different phases of in vitro cultivation (LLOYD; MCCOWN, 1980). $\mathrm{pH}$ was adjusted to $5.7 \pm 0.1$ with $1 \mathrm{~N} \mathrm{NaOH}$ and $1 \mathrm{~N} \mathrm{HCl}$, and the medium was then sterilized in an autoclave at $120^{\circ} \mathrm{C}$ and $20 \mathrm{lbs}$ pressure $(0.1 \mathrm{MPa})$ for $20 \mathrm{~min}$. It was supplemented with $2 \%(\mathrm{w} / \mathrm{v})$ sucrose and solidified with $1.8 \%(\mathrm{w} / \mathrm{v})$ phytagel. The cultures were maintained at a temperature of $23 \pm 1^{\circ} \mathrm{C}$ with a photoperiod of natural light with an average light period of $12 \mathrm{~h}$.

Table 1. Treatments evaluated using growth regulators for in vitro castor bean regeneration from epicotyls.

Treatments

$\mathbf{T}_{1}$

$\mathbf{T}_{2}$

$\mathbf{T}_{3}$

$\mathbf{T}_{4}$

$\mathbf{T}_{5}$

$\mathbf{T}_{6}$

$\mathbf{T}_{7}$

$\mathbf{T}_{8}$
Growth Regulators

$\mathrm{TDZ}[1 \mathrm{mg} / \mathrm{L}]$

TDZ [1mg/L] + 2ip [0.5mg/L]

TDZ [1mg/L] + Zeatin [0.5mg/L]

$\mathrm{TDZ}[1 \mathrm{mg} / \mathrm{L}]+\mathrm{BAP}[0.5 \mathrm{mg} / \mathrm{L}]$

TDZ [1mg/L] + Kinetin $[0.5 \mathrm{mg} / \mathrm{L}]$

TDZ $[1 \mathrm{mg} / \mathrm{L}]+$ IBA $[0.5 \mathrm{mg} / \mathrm{L}]$

TDZ $[1 \mathrm{mg} / \mathrm{L}]+$ NAA $[0.5 \mathrm{mg} / \mathrm{L}]$

Control 


\section{Rooting and acclimatization}

Once the shoots reached a length of $4 \mathrm{~cm}$, they were separated from the explant and sown in a culture medium supplemented with $[0.5$ and 1 $\mathrm{mg} / \mathrm{L}]$ of IBA and NAA (Table 2). After 6 weeks of growth, the following variables were evaluated: number of rooted plants and average number of roots per plant. The plants with a length of $4 \mathrm{~cm}$ and presence of roots were removed from the culture medium, washed with a sufficient amount of water, and then transferred to individual pots $(9 \times 10 \mathrm{~cm})$ containing a mixture of peat and sand (ratio, 3:1) previously sterilized in an autoclave. The plantlets were transferred to a greenhouse and covered with a punctured transparent plastic glass for the first 20 days. The substrate was moistened after every 4 days and fertilized every week with WPM basal salts, 1/2 WPM, or only water (control). After 60 days, the following variables were recorded: height, number of new leaves, number of shoots, number of roots, and survival rate.

Table 2. Effect of auxins on the rooting of adventitious shoots in castor bean variety VERC-02.

\begin{tabular}{cccc}
\hline Growth Regulators & Concentration [] & Rooting (\%) & $\begin{array}{c}\text { Average Number of } \\
\text { Roots }\end{array}$ \\
\hline NAA & $0.5 \mathrm{mg} / \mathrm{L}$ & $76,67^{\mathrm{b}}$ & $1,17^{\mathrm{b}}$ \\
& $1 \mathrm{mg} / \mathrm{L}$ & $93,33^{\mathrm{b}}$ & $2,23^{\mathrm{c}}$ \\
IBA & $0.5 \mathrm{mg} / \mathrm{L}$ & $66,67^{\mathrm{ab}}$ & $1,03^{\mathrm{ab}}$ \\
& $1 \mathrm{mg} / \mathrm{L}$ & $63,3^{\mathrm{ab}}$ & $1,27^{\mathrm{b}}$ \\
Control & - & $36,67^{\mathrm{a}}$ & $0,47^{\mathrm{a}}$ \\
\hline
\end{tabular}

Different letters indicate significant differences $(\mathrm{P} \leq 0.05)$.

\section{Statistical analysis}

The assumption of normality in the data was verified using the Shapiro-Wilk test. The differences between group pairs were evaluated using the Student's t-test when the data was normally distributed and using the Mann-Whitney test when the data was not normally distributed. The differences between more than two groups were evaluated using the Kruskal-Wallis test or ANOVA (in case of normality), followed by the pairwise Wilcoxon sum rank or Tukey HSD test, respectively, when at least one different group was found $(\alpha<0.05)$. All the statistical analyses were performed using the $\mathrm{R}$ 3.4.2 software (GENTLEMAN R, IHAKA R, 1997).

\section{RESULTS}

\section{Plant material and culture conditions}

Seeds established in the field were used for in vitro procedures. After 10 days, the seeds reached a germination of $71.7 \%$. However, the mature embryo rescue technique was used to increase the percentage of germination, increasing it to $91 \%$. On the other hand, $46.7 \%$ contamination, mainly caused by the late growth of bacteria, was recorded in the culture media, which suggested the endogenous presence of bacteria in the seed.

\section{Induction of shoots from epicotyls and seedling regeneration}

Sections of epicotyls were used as explants (Figure 1A), in some explants, callus formation was evident 8 days after sowing, without these inducing shoots which showed callus induction at 8 days of cultivation (Figure 1B). At 30 days in culture, the proliferation of adventitious shoots was observed in the evaluated treatments, including the control (Figure 1C). However, not all explants responded to the shoots developed.

The highest number of adventitious shoots (4.3 shoots/section) and frequency $(75,56 \%)$ was present in the medium supplemented with TDZ [1 $\mathrm{mg} / \mathrm{L}]$ and zeatin $[0.5 \mathrm{mg} / \mathrm{L}]$ (T5) $\mathrm{P} \leq 0.05$ (Table $3)$. The lowest number of shoots per explant $(0.8$ shoots/section) and lowest frequency $(37,78 \%)$ was recorded in the medium supplemented with TDZ [1 $\mathrm{mg} / \mathrm{L}]$ and BAP $[0.5 \mathrm{mg} / \mathrm{L}]$ (T4) (Table 3). 

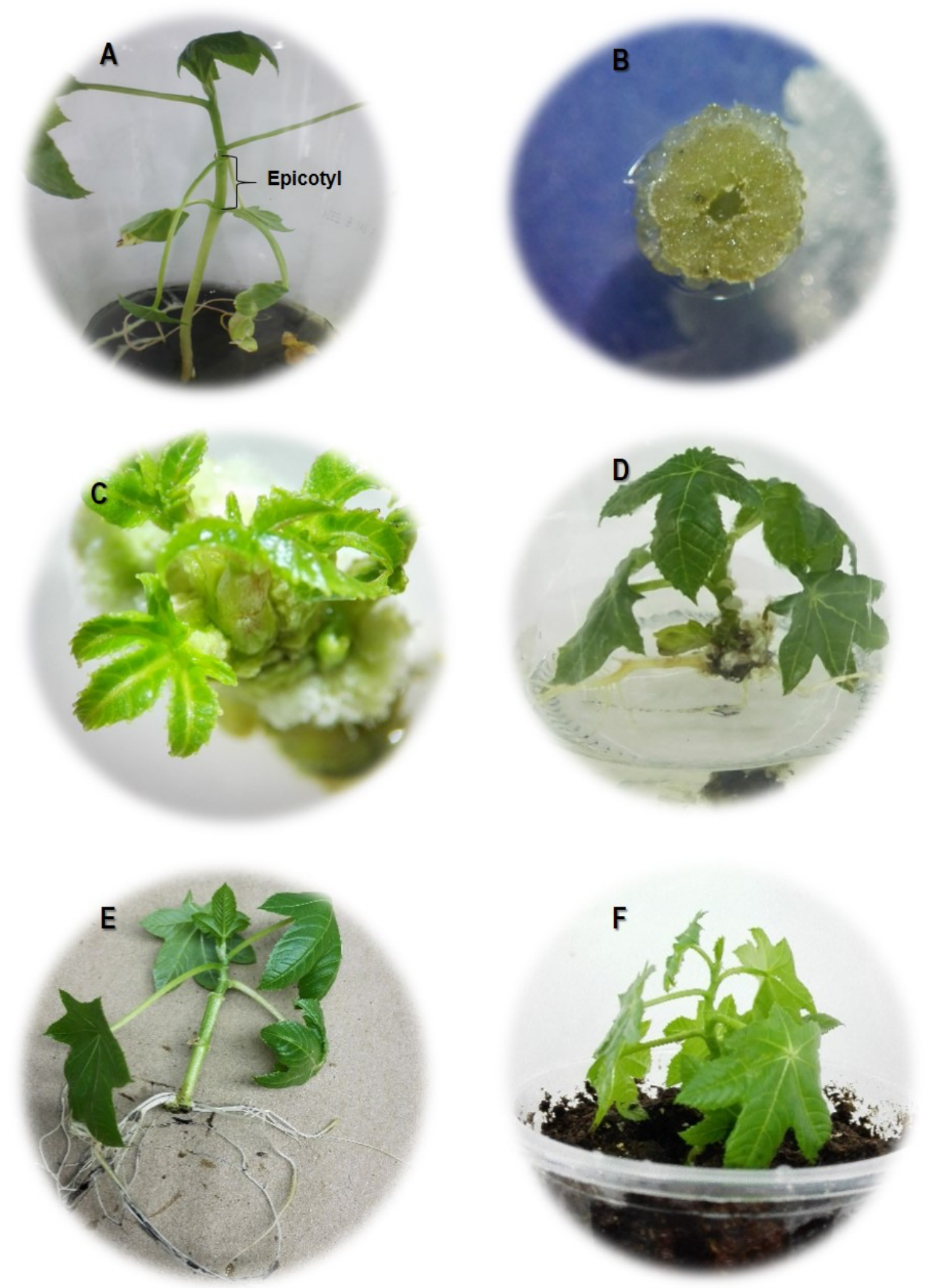

Figure 1. A. Epicotyl section of castor bean used for regeneration B. Friable castor bean callus from epicotyl sections without these inducing shoots $\mathbf{C}$. Adventitious shoots formed from epicotyl sections $\mathbf{D}$. Elongated shoots from epicotyl sections in control medium E. Rooted castor bean seedling F. Hardened castor bean plant using WPM nutritive salts. 
Table 3. Effect of growth regulators on cultures obtained from castor bean of the variety VERC-02 after 45 days of cultivation, including the total number of shoots, average shoots per explant, callus percentage, and percentage of elongated shoots of $>2.5 \mathrm{~cm}$.

\begin{tabular}{cccc}
\hline Hormonal Treatments & $\begin{array}{c}\text { Average of shoots } \\
\text { per explant }\end{array}$ & $\begin{array}{c}\text { Shoots Frequency } \\
(\mathbf{\%})\end{array}$ & $\begin{array}{c}\text { Percentage of } \\
\text { elongated shoots } \\
(>\mathbf{2 . 5 c m})\end{array}$ \\
\hline$\left(\mathbf{T}_{\mathbf{1}}\right)$ & $0,92^{\mathrm{ab}}$ & $44,44^{\mathrm{a}}$ & $33,33^{\mathrm{cd}}$ \\
$\left(\mathbf{T}_{\mathbf{2}}\right)$ & $1,17^{\mathrm{abc}}$ & $42,22^{\mathrm{a}}$ & $13,33^{\mathrm{ab}}$ \\
$\left(\mathbf{T}_{\mathbf{3}}\right)$ & $1,08^{\mathrm{abc}}$ & $46,67^{\mathrm{a}}$ & $23,7^{\mathrm{bc}}$ \\
$\left(\mathbf{T}_{\mathbf{4}}\right)$ & $0,81^{\mathrm{a}}$ & $37,78^{\mathrm{a}}$ & $5,56^{\mathrm{ab}}$ \\
$\left(\mathbf{T}_{\mathbf{5}}\right)$ & $4,30^{\mathrm{d}}$ & $75,56^{\mathrm{b}}$ & $15,37^{\mathrm{cd}}$ \\
$\left(\mathbf{T}_{\mathbf{6}}\right)$ & $1,31^{\mathrm{abc}}$ & $44,44^{\mathrm{a}}$ & $0^{\mathrm{a}}$ \\
$\left(\mathbf{T}_{7}\right)$ & $1,33^{\mathrm{bc}}$ & $46,67^{\mathrm{a}}$ & $18,76^{\mathrm{bc}}$ \\
$\mathbf{C o n t r o l}^{\mathrm{cc}}$ & $1,97^{\mathrm{cd}}$ & $57,78^{\mathrm{c}}$ & $34,15^{\mathrm{d}}$ \\
\hline
\end{tabular}

Different letters indicate statistically different groups $(\mathrm{p} \leq 0.05)$

In all the treatment protocols, the percentage of elongated shoots was very similar; however, the highest percentage of elongated shoots was obtained in the control medium (Figure 1D) (Table 3). Also, slow development was observed once the regenerated shoots were disconnected; in some cases, tissue necrosis and subsequent death were observed. Given this situation, rooting was assessed in shoots that exceeded $3.0 \mathrm{~cm}$ in length.

\section{Rooting and acclimatization}

After 30 days of cultivation in the rooting medium, the presence of small roots in some IBAtreated shoots was observed. At 45 days of cultivation, a greater number of rooted plants was observed (Table 3). The statistical analysis showed a significant difference in the rooting percentage and number of roots between the concentrations of growth regulators NAA and IBA compared with the control $(\mathrm{P} \leq 0.05)$. The highest percentage of rooted plants $(93.3 \%)$ was observed in the medium supplemented with IBA[1 mg/L] whereas the lowest percentage $(36.7 \%)$ was observed in the control medium (Figure 1E).

The rooted plants were transplanted and transferred to a mesh house, where they showed high adaptability to acclimatization with a $77 \%$ survival rate. A greater height $(7.9 \mathrm{~cm})$ was obtained after 2 months in the acclimatization stage for plants that were supplemented with WPM nutrients than in the controls $(4.38 \mathrm{~cm})$. Similarly, the average number of leaves and roots per plant was significantly increased during the acclimatization phase (Figure 1F and Table 4). 
Table 4. Survival rate, average height, and number of leaves, roots, and shoots of plants after 60 days of hardening. Different letters indicate significant differences $(\mathrm{P} \leq 0.05)$.

\begin{tabular}{cccccc}
\hline $\begin{array}{c}\text { Media } \\
\text { Treatments }\end{array}$ & Survival rate & Mortality rate & $\begin{array}{c}\text { Average } \\
\text { height }(\mathbf{c m})\end{array}$ & $\begin{array}{c}\text { Average of } \\
\text { leaves }\end{array}$ & $\begin{array}{c}\text { Average of } \\
\text { roots }\end{array}$ \\
\hline $\mathbf{W P M}$ & $76,67^{\mathrm{a}}$ & $23,00^{\mathrm{a}}$ & $7,96^{\mathrm{a}}$ & $3,63^{\mathrm{a}}$ & $1,9^{\mathrm{a}}$ \\
$\mathbf{W P M} / \mathbf{2}$ & $33,3^{\mathrm{b}}$ & $66,67^{\mathrm{b}}$ & $6,69^{\mathrm{b}}$ & $1,7^{\mathrm{b}}$ & $0,73^{\mathrm{b}}$ \\
Control & $13,33^{\mathrm{b}}$ & $86,67^{\mathrm{b}}$ & $4,38^{\mathrm{c}}$ & $1,3^{\mathrm{b}}$ & $0,6^{\mathrm{b}}$
\end{tabular}

Different letters indicate statistically different groups ( $\mathrm{p} \leq 0.05)$.

\section{DISCUSSION}

During this research project, the laboratory procedures were standardized from the establishment to the elongation phase, including the rooting and hardening of shoots regenerated in vitro, starting from epicotyls and using the WPM basal medium. Although the use of MS basal media has generally been reported for in vitro castor bean cultivation, problems have been encountered due to their recalcitrant nature (REDDY, K.; BAHADUR, 1989; REDDY, K. R. K., BHADUR, 1994; GANESH KUMARI, GANESAN, JAYABALAN, 2008). In this study, a high percentage of germination $(91 \%)$ and significant number of induced and developed shoots were obtained by rescuing mature embryos (Table 3). This favorable result was probably due to the use of the basal medium (WPM), which has a lower concentration of nitrogen $\left(\mathrm{NH}_{4} \mathrm{NO}_{3}\right.$ and $\left.\mathrm{Ca}\left(\mathrm{NO}_{3}\right)_{2} \quad 4 \mathrm{H}_{2} \mathrm{O}\right)$ sources, which may be toxic to some species cultured using the MS medium (RESTREPO C, GIL A, GÓMEZ F, TORRES J, 2018).

Cytokinins have been commonly used to enhance the formation of adventitious sprouts in plants. They are essential hormones in the sprout regeneration process in many fruit species, such as Citrus sinensis (MAGGON, SINGH, 1995), Annona squamosa (NAGORI, PUROHIT, 2004), and Rollinia mucosa (FIGUEIREDO, ALBARELLO, CAMPOS VIANA, 2001). In many plants of the family Euphorbiaceae, only the presence of cytokinins promotes the optimal proliferation of shoots, as observed in Euphorbia lathyris using N6(2-isopentenil adenosine) (LEE, C. W., YECKES, J.; THOMAS, 1982) and in $R$. communis using a combination of the growth regulators BAP [2.5 $\mathrm{mg} / \mathrm{L}]$ and NAA [0.1 mg/L] (SARVESH, A., RAM RAO, D. M.; REDDY, 1992).

In cytokinins, TDZ presents several advantages for being especially effective in shoot regeneration, acting alone or in combination with other growth regulators, which was determined in different species of herbaceous plant (ZHANG et al., 2001; RAMÍREZ-MOSQUEDA, 2015) as well as woody plant species (RESTREPO C, GIL A, GÓMEZ F, TORRES J, 2018), and some members of Euphorbiaceae family (KUMAR; VIJAY ANAND; REDDY, 2010; RESTREPO C, GIL A, GÓMEZ F, TORRES J, 2018). Kumar, and Reddy(2012) induced plant regeneration from cotyledonary petiole explants of Jatropha curcas, it achieved optimum concentration for the induction of shoot bud MS medium supplemented with $2.27 \mu \mathrm{M}$ TDZ, they reached up to $51 \%$ of shoot bud induction, and reach up to 9.75 as number as of induced shoot buds per explants. In this study, since epicotyl sections achieved on WPM medium supplemented with TDZ was important in terms of the number of shoots induced, reaching up to 4.3 shoots and $75 \%$ of shoot frequency induction per epicotyl section. In other species, a significant number of shoots induced from epicotyls can be achieved using other cytokinins, such as BAP (up to 6.7 shoots/explant) in Citrus jambhiri Lush (RATTANPAL; KAUR; GUPTA, 2011) and (7.7 shots/explant) in Cassia angustifolia Vahl (SIDDIQUE et al., 2013).

Once the regeneration of the adventitious shoots is achieved, an efficient mechanism for rooting them should be established to guarantee successful micropropagation and subsequent survival of these explants in the acclimatization phase. This study showed that $93.3 \%$ of plants 
showed rooting and an average of 2.23 roots/shoot was obtained in the medium supplemented with [1 $\mathrm{mg} / \mathrm{L}]$ of NAA what contrasts with (KANSARA et al., 2013) who achieved only $69 \%$ rooting in castor beans; notwithstanding, they obtained 5.33 roots/shoot in a medium supplemented with [0.1 $\mathrm{mg} / \mathrm{L}]$ NAA. Although growth regulators, such as IBA and AIA (AHN et al., 2007), have been used for the in vitro rooting of castor bean plants, it has been evidenced that NAA is ideal for the rooting of adventitious shoots in these plants (SUJATHA et al., 2009; ALAM et al., 2010; KANSARA et al., 2013;).

Hardening is the last stage for successful micropropagation but is also the most critical for the survival of the explant, so water stress should be minimized, retaining moisture for a long period of time. Therefore, peat was used as a substrate and maintained with periodic irrigation to avoid excess watering and prevent the growth of microorganisms that can affect the growth and development of the seedlings. The results obtained in this phase showed that nutrient concentration affected plant growth. The plants supplemented with complete WPM showed better growth and development than those supplemented with half the concentration of WPM and control (Table 4). Alam et al. (2010) achieved $60 \%$ survival in hardened castor bean plants in their study, with $77 \%$ survival of plants under nursery conditions.

\section{CONCLUSIONS}

Castor bean species is of great agricultural interest; hence, generating strategies that boost its propagation using techniques like in vitro plant cultivation provides an excellent alternative for the clonal multiplication of notable varieties.

The present study successfully obtained regenerated shoots directly using cross sections of epicotyls from germinated plants in vitro.

The sprouts obtained were elongated and rooted until they developed into a new hardened seedling in the substrate.

The results showed that castor bean epicotyls have high, direct organogenic potential and can thus be used as an alternative for micropropagation and genetic improvement.

\section{ACKNOWLEDGMENTS}

We would like to thank the Colombian General Royalty System (SGR, Spanish acronym), Secretaría de Agricultura y Desarrollo Rural of Departamento de Antioquia, Universidad Pontificia Bolivariana, Universidad Nacional de Colombia and Universidad EAFIT for funding in the convening "project code 4600000480 ". We would also like to thank Colombian Agricultural and Livestock Research Corporation (in Spanish, Corporación Colombiana de Investigación Agropecuaria or AGROSAVIA), for providing seeds and technical support in this research field.

RESUMO: Foi desenvolvido com sucesso um protocolo de regeneração para a planta de Mamona (Ricinus communis) utilizando seções de epicótilos, obtidas a partir de mudas in vitro. O número máximo de brotações induzidas ( 4.3 brotos/explante), assim como a maior frequência de brotações $(75,56 \%)$, foi obtido em meio WPM suplementado com TDZ $(1 \mathrm{mg} / \mathrm{L})$ e zeatina $(0,5 \mathrm{mg} / \mathrm{L})$. Enquanto que o número mínimo $(0,8$ brotos/explante), como a menor frequiência de rebentos (37,78\%), foi obtido em meio contendo TDZ (1 mg/L) e BAP $(0,5 \mathrm{mg} / \mathrm{L})$. Adicionalmente, a maior percentagem de enraizamento $(93,3 \%)$ foi obtida em um meio contendo IBA (1 mg/L). Depois da regeneração, as plantas foram transplantadas em casa de vegetação e conseguiram uma alta adaptabilidade e aclimatização, atingindo $77 \%$ de sobrevivência. Por outro lado, o alongamento máximo (altura) durante este estágio foi de $7,9 \mathrm{~cm}$ em plantas suplementadas com nutrientes de WPM, enquanto as plantas de controle presentaram apenas $4,38 \mathrm{~cm}$.

PALAVRAS CHAVE: Organogênese. Aclimatação. Enraizamento. Cultura tropical. Tecidos vegetais. Oleaginosas.

\section{REFERENCES}

AHN, Y. J. et al. High-frequency plant regeneration through adventitious shoot formation in castor (Ricinus communis L.). In Vitro Cellular and Developmental Biology - Plant, v. 43, n. 1, p. 9-15, 2007. https://doi.org/10.1007/s11627-006-9009-2 
AHN, Y. J.; CHEN, G. Q. In vitro regeneration of castor (Ricinus Communis L.) using cotyledon explants. HortScience, v. 43, n. 1, p. 215-219, 2008.

ALAM, I. et al. In vitro micropropagation through cotyledonary node culture of castor bean (Ricinus communis L.). Australian Journal of Crop Science, v. 4, n. 2, p. 81-84, 2010.

FAOSTAT. Disponível em: <http://www.fao.org/faostat/es/\#data/QC>. Acesso em: 22 nov. 2017.

FERNÁNDEZ-MARTINEZ, J. M.; VELASCO, L. Technological innovations in major world oil crops. Volume 1, Breeding. In: GUPTA, S. K. (Ed.). . Technological innovations in major world oil crops. 1. ed. [s.1.] Springer, 2012. p. 405.

FIGUEIREDO, S. F. L.; ALBARELLO, N.; CAMPOS VIANA, V. R. Micropropagation of Rollinia mucosa (JACQ.) baill. In Vitro Cellular \& Developmental Biology - Plant, v. 37, n. 4, p. 471-475, jul. 2001. https://doi.org/10.1007/s11627-001-0083-1

GANESH KUMARI, K.; GANESAN, M.; JAYABALAN, N. Somatic organogenesis and plant regeneration in Ricinus communis. Biologia Plantarum, v. 52, n. 1, p. 17-25, mar. 2008. https://doi.org/10.1007/s10535-0080003-X

GENTLEMAN R, IHAKA R, et al. R softwareAuckland, 1997. Disponível em: <https://www.r-project.org/>

KANSARA, R. et al. An efficient protocol for in vitro mass propagation of Fusarium wilt resistant castor (Ricinus communis L.) parental line Skp-84 through apical meristem. The Bioscan, v. 8, p. 403-408, 2013.

KUMAR, N.; REDDY, M. P. Thidiazuron (TDZ) induced plant regeneration from cotyledonary petiole explants of elite genotypes of Jatropha curcas: a candidate biodiesel plant. Industrial crops and products, v. 39, p. 62-68, 2012. https://doi.org/10.1016/j.indcrop.2012.02.011

KUMAR, N.; VIJAY ANAND, K. G.; REDDY, M. P. In vitro plant regeneration of non-toxic Jatropha curcas L.: Direct shoot organogenesis from cotyledonary petiole explants. Journal of Crop Science and

Biotechnology, v. 13, n. 3, p. 189-194, 2010. https://doi.org/10.1007/s12892-010-0039-2

LEE, C. W., YECKES, J.; THOMAS, J. C. Tissue-culture propagation of Euphorbia-lathyris and Asclepias erosa. HortScience, v. 17, n. 3, p. 533, 1982.

LLOYD, G.; MCCOWN, B. Commercially-feasible micropropagation of mountain laurel, Kalmia latifolia, by use of shoot-tip culture. Combined Proceedings, International Plant Propagators' Society, v. 30, p. 421427, 1980.

MAGGON, R.; SINGH, B. D. Promotion of adventitious bud regeneration by ABA in combination with BAP in epicotyl and hypocotyl explants of sweet orange (Citrus sinensis L. Osbeck). Scientia Horticulturae, v. 63, n. 1, p. 123-128, 1995. https://doi.org/10.1016/0304-4238(95)00780-W

MEDEROS MOLINA, S.; SCHOBERT, C. Micropropagation of Ricinus communis. Journal of Plant Physiology, v. 147, n. 2, p. 270-272, 1 jan. 1995. https://doi.org/10.1016/S0176-1617(11)81517-8

NAGORI, R.; PUROHIT, S. D. In vitro plantlet regeneration in Annona squamosa through direct shoot bud differentiation on hypocotyl segments. Scientia Horticulturae, v. 99, n. 1, p. 89-98, 2 jan. 2004. https://doi.org/10.1016/S0304-4238(03)00084-0

RAMÍREZ-MOSQUEDA, M. Indirect organogenesis and assessment of somaclonal variation in plantlets of Vanilla planifolia Jacks. Plant Cell Tissue and Organ Culture, v. 123, 2015. 
RATTANPAL, H.; KAUR, G.; GUPTA, M. In vitro plant regeneration in rough lemon (Citrus jambhiri Lush) by direct organogenesis. African Journal of Biotechnology, v. 10, n. 63, p. 13724-13728, 2011. https://doi.org/10.5897/AJB09.1264

REDDY, K.; BAHADUR, B. Adventitious bud formation from leaf cultures of castor (Ricinus communis 1.). current science, v. 58, n. 3, p. 152-154, 1989.

REDDY, K. R. K., BHADUR, B. Somatic embryogenesis in castor (Ricinus communis L.). Adv. Plant Sci, v. 7, p. 163-169, 1994.

RESTREPO C, GIL A, GÓMEZ F, TORRES J, U. A. In vitro propagation of avocado (Persea americana) cv. Hass by morphogenesis. Acta Agronómica, 2018. https://doi.org/10.15446/acag.v67n1.61474

SAILAJA, M.; TARAKESWARI, M.; SUJATHA, M. Stable genetic transformation of castor (Ricinus communis L.) via particle gun-mediated gene transfer using embryo axes from mature seeds. Plant Cell Reports, v. 27, n. 9, p. 1509-1519, 2008.

SARVESH, A., RAM RAO, D. M.; REDDY, T. P. Callus initiation and plantlet regeneration from epicotyl and cotyledonary explants of castor (Ricinus communis L.). Adv Plant Sci, v. 5, p. 124-128, 1992.

SIDDIQUE, I. et al. Stimulation of in vitro organogenesis from epicotyl explants and successive micropropagation round in Cassia angustifolia Vahl.: An important source of sennosides. Agroforestry Systems, v. 87, n. 3, p. 583-590, 2013. https://doi.org/10.1007/s10457-012-9578-5

SINGH, A. S. et al. Role of conventional and biotechnological approaches in genetic improvement of castor (Ricinus communis L.)Industrial Crops and ProductsElsevier, , 15 nov. 2015. Disponível em: <http://www.sciencedirect.com/science/article/pii/S0926669015300789>. Acesso em: 22 nov. 2017

SUJATHA, M. et al. Expression of the cry1EC gene in castor (Ricinus communis L.) confers field resistance to tobacco caterpillar (Spodoptera litura Fabr) and castor semilooper (Achoea janata L.). Plant Cell Reports, v. 28, n. 6, p. 935-946, jun. 2009. https://doi.org/10.1007/s00299-009-0699-x

SUJATHA, M.; MAKKAR, H. P. S.; BECKER, K. Shoot bud proliferation from axillary nodes and leaf sections of non-toxic Jatropha curcas L. Plant Growth Regulation, v. 47, n. 1, p. 83-90, 2005. https://doi.org/10.1007/s10725-005-0859-0

SUJATHA, M.; REDDY, T. P. Differential cytokinin effects on the stimulation of in vitro shoot proliferation from meristematic explants of castor (Ricinus communis L.). Plant Cell Reports, v. 17, n. 6-7, p. 561-566, 1998. https://doi.org/10.1007/s002990050442

ZHANG, C.-L. et al. Thidiazuron-induced organogenesis and somatic embryogenesis in sugar beet (Beta vulgaris L.). In Vitro Cellular \& Developmental Biology - Plant, v. 37, n. 2, p. 305-310, mar. 2001. https://doi.org/10.1007/s11627-001-0054-6 